\title{
Systematic review of the temporalis muscle used in head and neck reconstruction
}

\section{Original Article}

\author{
Mohamed Abdel-Mobde ${ }^{a}$,Sameh Mekhamir ${ }^{b}$, Heba Sleem ${ }^{c}$ and Moustafa Taha ${ }^{c}$ \\ Department of Oral and Maxillofacial Surgery, Faculty of Dentistry, ${ }^{a}$ Future \\ University, ${ }^{b}$ Ciaro University, ${ }^{c}$ Ain Shams University, Cairo, Egypt
}

\begin{abstract}
Background: The temporalis muscle flap (TMF) has emerged as a popular option in head and neck reconstruction in the last decade. The purpose of this study was to conduct a literature review of the temporalis muscle flap.

Methods: We have conducted a search on PubMed using specific keywords to identify all articles related to the Temporalis Muscle Flap. We reviewed the modifications of the Temporalis Muscle Flap, its indications, contraindications, complications, and outcomes.

Results: After application of the inclusion criteria and reading the abstract. A five articles were included for the review and the most commonly used site was the Temporo-Mandibular Joint as interpositional material after gap arthroplasty. Functional and aesthetic outcomes were judged to be excellent.

Conclusion: From The Temporalis Muscle Flap is a versatile reconstructive option for the treatment of ankylosis, as it is highly vascular flap with close proximity to the site of surgery. Recent studies have explored new applications for this flap, such as in skull base reconstruction.
\end{abstract}

Key Words: Head and neck defects, Oft tissue defects, Oral cavity, Palatal reconstruction and Temporalis muscle flap.

Received: 02 Februray 2020, Accepted: 04 September 2020.

Corresponding Author: Mohamed Abdel-Mobde, Department of Oral and Maxillofacial Surgery, Faculty of Dentistry, Future University, Cairo, Egypt, Tel.: +20222639083, Mobile: +201003368183, E-mail: dr.farouk.ace@gmail.com.

ISSN: 2090-097X, January 2020, Vol. 11, No. 1.

\section{INTRODUCTION}

The resection of palatomaxillary tumors usually result in significant functional, esthetic, and psychological problems ${ }^{[1]}$. The resulting defects are usually composite and thus representing a great difficulty in the reconstructive procedure $^{[2]}$. A large spectrum of reconstructive options exists depending on the nature and size of the defects. Each reconstruction technique has its own advantages and disadvantages. But harvesting free flaps is time-consuming and also requires surgical expertise in microsurgery ${ }^{[3]}$. Over the last decades, the use of regional pedicled flaps, such as the submental flap, the supraclavicular flap, the facial artery musculomucosal (FAMM) flap, or the temporalis muscle flap, has been increasingly documented in the literature. The origin of the temporalis muscle flap has been attributed to Golovine in 1898, a Moscow ophthalmic surgeon, who described a forehead skin transposition flap for obliteration of dead space following orbital exenteration ${ }^{[4]}$, but the use of the majority of the muscle for reconstruction of facial defects was first described by sir Harold Gillies during the 191418- war $^{[5]}$ where it was tunneled to either the corner of mouth or the inner canthus of the ey $\mathrm{e}^{[6]}$.

\section{METHODOLOGY}

An electronic search in the PubMed-MEDLINE and Cochrane databases was conducted including the following key words "Temporalis muscle flap", "palatal reconstruction", "oral cavity", "head and neck defects" and "soft tissue defects" with a cutoff point of December 2017.

\section{Inclusion criteria}

- Clinical trials only.

- Studies on human specimen only.

- Studies on patients with systemic diseases are included.

- Prospective or retrospective studies will be included.

- A minimum follow-up period of six months.

\section{Exclusion criteria}

- Studies having less than 6 months follow up.

- Articles having experimental studies.

- Studies other than clinical trials.

- Non English articles.

- Articles failed to gain information about graft success were excluded.

We scrutinized the citations of included articles to identify additional relevant articles that could have been missed by using the PubMed keywords search. 


\section{RESULTS}

The electronic search using the term "temporalis muscle flap" resulted in total of 915 articles. After exclusion of animal studies a total of 822 articles were obtained. We only intended to include clinical trials and to exclude review articles, case reports and met analyses. Consequently, the number of clinical trials obtained from the previous pool comprised 15 articles only. Hand searching of the references in the selected 15 articles and through Ain shams dental school library did not reveal any new ones that match our predetermined criteria. After reviewing the abstracts of the selected 15 articles, 10 were excluded because of irrelevance in relation to our criteria.
This left us with a total of 5 full text articles which will be discussed thoroughly through this review (Figure 1).

The full search was used to construct the PRISMA (Preferred Reporting Items for Systematic Review and Meta-Analysis) flow chart.

\section{Included studies}

All five studies were finished between (1991 - 2009). Two studies (S. M. Balaji, 2003) and (Danda, S, AND Chinnaswami, 2009) was conducted in India; (Wong et al., 2004) was done in Taiwan; (Yazdani 2010) was conducted in Iran, while (He 2011) was in USA (Table 1 and 2).

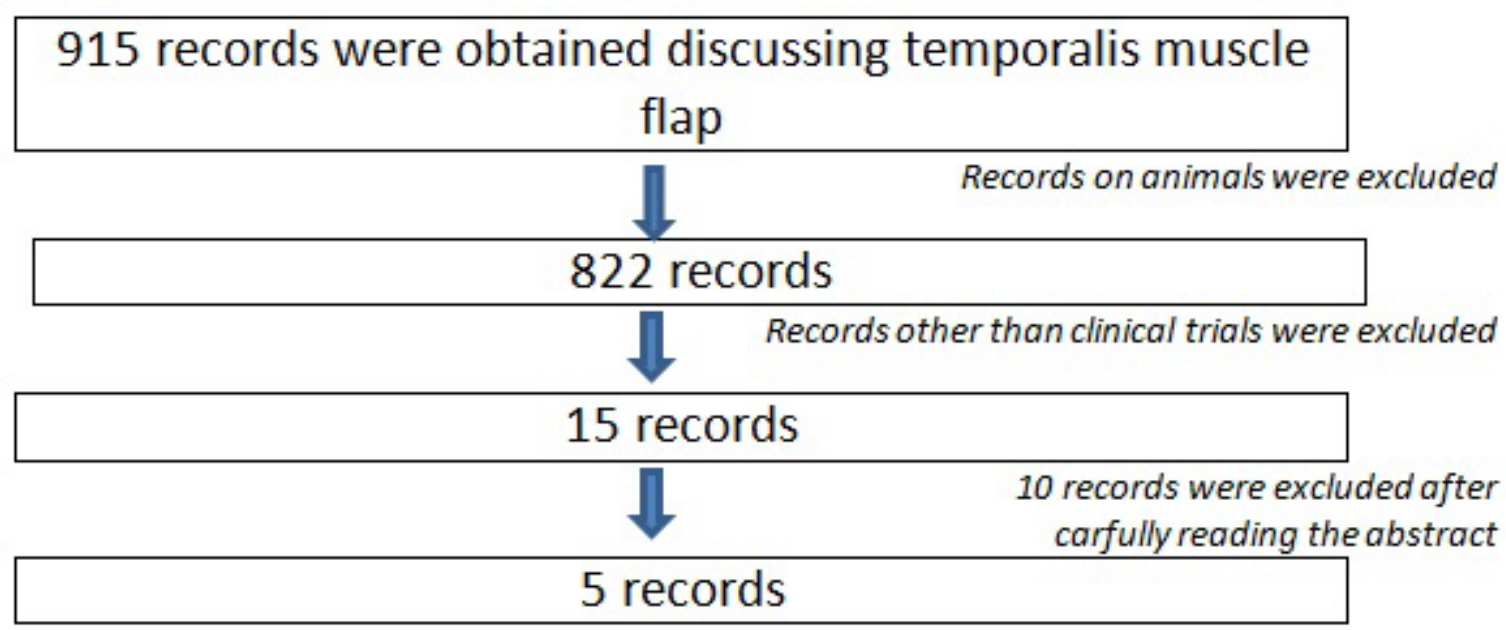

Figure 1: Diagram showing the included articles.

Table 1: Showing the included articles:

\begin{tabular}{lll}
\hline Authors and Date & Title & Type of study \\
\hline $\begin{array}{l}\text { S. M. Balaji, 2003 } \\
\text { Wong et al., 2004 }\end{array}$ & $\begin{array}{l}\text { Modified temporalis anchorage in craniomandibular reankylosis } \\
\text { The Inverted Temporalis Muscle Flap for Intraoral Reconstruction: Its Rationale } \\
\text { and the Results of Its Application }\end{array}$ \\
Danda,S,AND Chinnaswami, 2009 & $\begin{array}{l}\text { Comparison of gap arthroplasty with and without a temporalis muscle flap for Randomized controlled trial } \\
\text { the treatment of ankylosis }\end{array}$ \\
Yazdani et al., 2010 & $\begin{array}{l}\text { Comparison of clinical efficacy of temporalis myofascial flap and dermal graft as Randomized controlled trial } \\
\text { interpositional material in treatment of TMJ ankylosis } \\
\text { He et al., 2011 }\end{array}$ & $\begin{array}{l}\text { Surgical treatment of traumatic TMJ ankylosis with medially displaced residual Retrospective study } \\
\text { condyle }\end{array}$ \\
\hline
\end{tabular}


Table 2: Showing included articles characteristics:

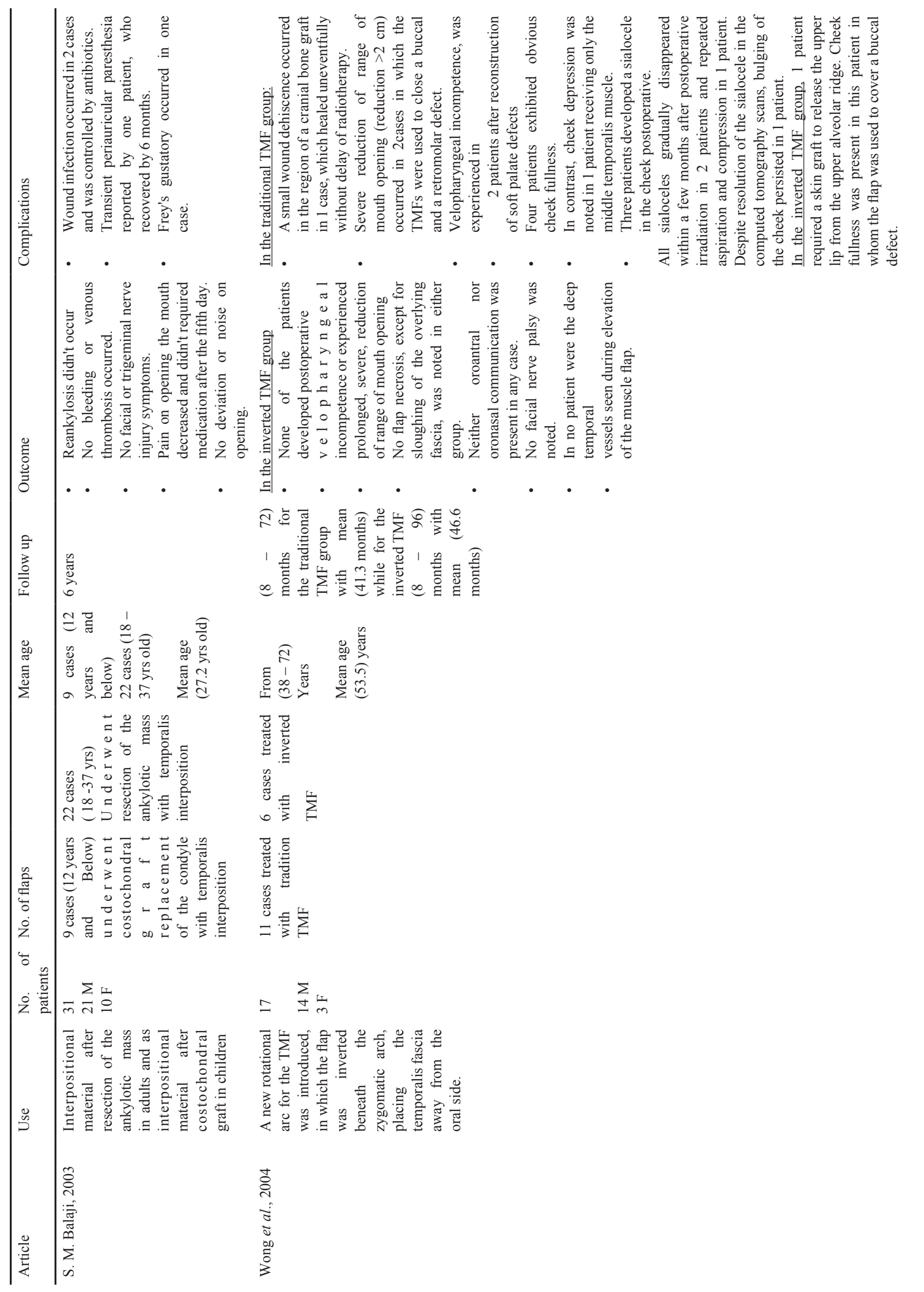




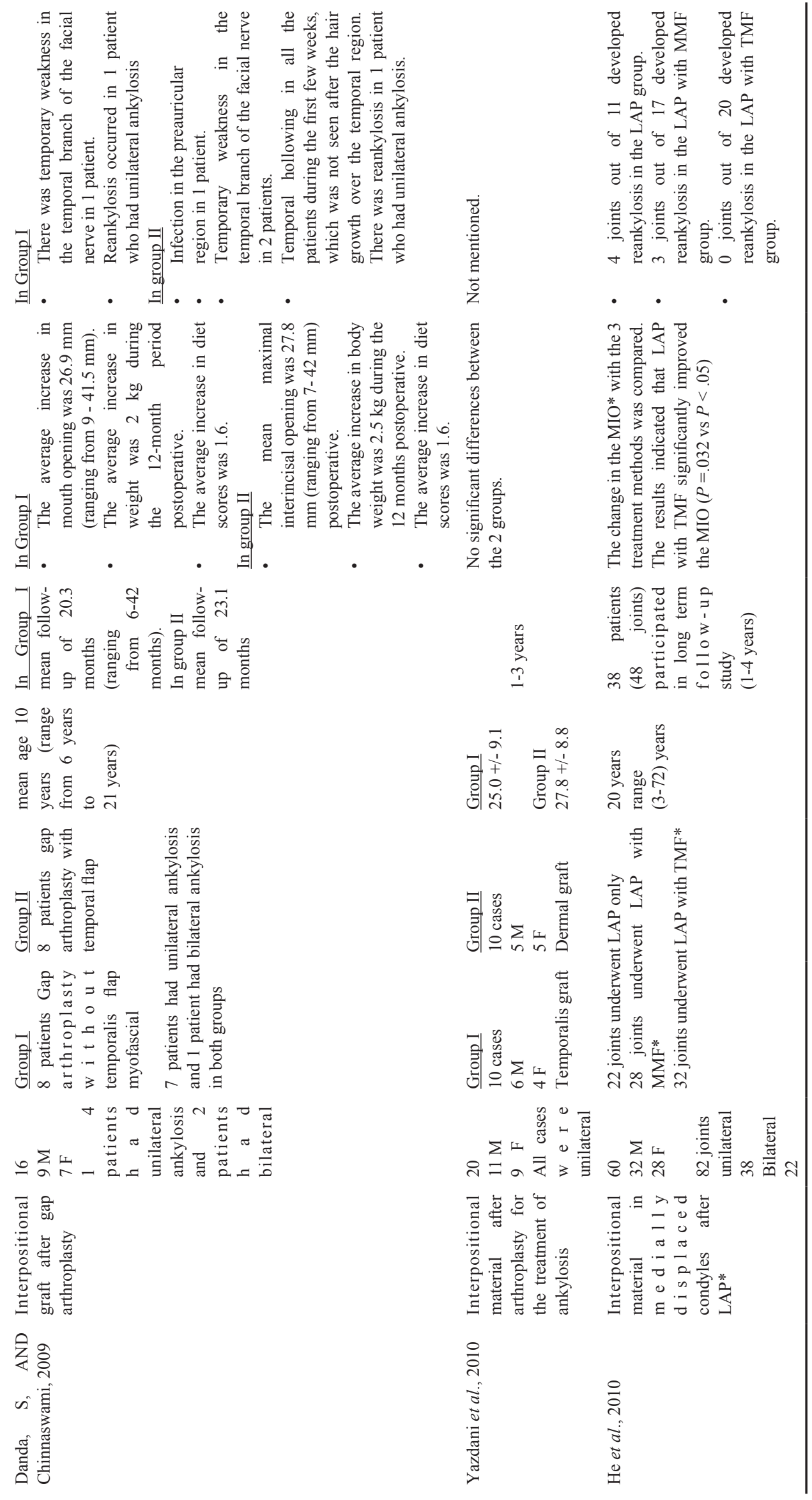




\section{Design and methods}

All studies used the temporalis muscle flap as a treatment for ankylosis by using it as interpositional material and comparing this with other interventions, exception for (Wong et al., 2004) introduced a new technique for harvesting the muscle.

\section{Participants}

The total numbers of patients participating in the 5 included studies were 144 participants and ranged from 16 in the smallest trial (Danda, S, AND Chinnaswami, 2009) to 60 in the largest trial (He et al., 2011).

\section{Risk of bias in included studies}

Detailed descriptions of the risk of bias for the included studies in (Tables 3, 4, 5, 6, 7).

Table 3: Risk of bias (S. M. Balaji, 2003):

\begin{tabular}{|l|ll}
$\begin{array}{l}\text { Random sequence } \\
\text { generation } \\
\text { bias) }\end{array}$ & Low risk & $\begin{array}{l}\text { Patients randomly divided } \\
\text { into 2 groups using block } \\
\text { randomization }\end{array}$ \\
$\begin{array}{l}\text { Allocation concealment } \\
\text { (selection bias) }\end{array}$ & Unclear risk & $\begin{array}{l}\text { The study doesn't include } \\
\text { any description of } \\
\text { allocation concealment }\end{array}$ \\
$\begin{array}{l}\text { Blinding o participants } \\
\text { and personnel } \\
\text { (performance bias) }\end{array}$ & Unclear risk & $\begin{array}{l}\text { it wasn't mentioned if the } \\
\text { participants were blinded } \\
\text { Blinding of outcome } \\
\text { assessment (detection } \\
\text { bias) }\end{array}$ \\
$\begin{array}{l}\text { Incomplete outcome } \\
\text { data (attrition bias) }\end{array}$ & Low risk & $\begin{array}{l}\text { It wasn't possible to blind } \\
\text { the assessor }\end{array}$ \\
$\begin{array}{l}\text { Selective reporting } \\
\text { (reporting bias) }\end{array}$ & Unclear risk & $\begin{array}{l}\text { No missing outcome data } \\
\text { Other bias study protocol is not }\end{array}$ \\
\end{tabular}

Table 4: Risk of bias (Wong et al., 2004):

\begin{tabular}{|l|ll}
$\begin{array}{l}\text { Random sequence } \\
\text { generation } \\
\text { bias) }\end{array}$ & Low risk & $\begin{array}{l}\text { Patients randomly divided } \\
\text { into 2 groups using block } \\
\text { randomization }\end{array}$ \\
$\begin{array}{l}\text { Allocation concealment } \\
\text { (selection bias) }\end{array}$ & Unclear risk & $\begin{array}{l}\text { The study doesn't include } \\
\text { any description of } \\
\text { allocation concealment }\end{array}$ \\
$\begin{array}{l}\text { Blinding of participants } \\
\text { and personnel } \\
\text { (performance bias) }\end{array}$ & Unclear risk & $\begin{array}{l}\text { it wasn't mentioned if the } \\
\text { participants were blinded } \\
\text { Blinding of outcome } \\
\text { assessment (detection } \\
\text { bias) }\end{array}$ \\
$\begin{array}{l}\text { Incomplete outcome } \\
\text { data (attrition bias) }\end{array}$ & Low risk & $\begin{array}{l}\text { It wasn't possible to blind } \\
\text { the assessor }\end{array}$ \\
$\begin{array}{l}\text { Selective reporting } \\
\text { (reporting bias) }\end{array}$ & Unclear risk & $\begin{array}{l}\text { No missing outcome data } \\
\text { Other bias study protocol is not }\end{array}$ \\
\end{tabular}

Table 5: Risk of bias (Danda, S, AND Chinnaswami, 2009):

\begin{tabular}{|l|ll}
$\begin{array}{l}\text { Random sequence } \\
\text { generation } \begin{array}{l}\text { (selection } \\
\text { bias) }\end{array}\end{array}$ & Low risk & $\begin{array}{l}\text { Patients randomly divided } \\
\text { into 2 groups using block } \\
\text { randomization }\end{array}$ \\
$\begin{array}{l}\text { Allocation concealment } \\
\text { (selection bias) }\end{array}$ & Unclear risk & $\begin{array}{l}\text { The study doesn't include } \\
\text { any description of } \\
\text { allocation concealment }\end{array}$ \\
$\begin{array}{l}\text { Blinding of participants } \\
\text { and personnel } \\
\text { (performance bias) }\end{array}$ & Unclear risk & $\begin{array}{l}\text { it wasn't mentioned if the } \\
\text { participants were blinded } \\
\text { Blinding of outcome } \\
\text { assessment (detection } \\
\text { bias) }\end{array}$ \\
$\begin{array}{l}\text { Incomplete outcome } \\
\text { data (attrition bias) }\end{array}$ & Low risk & $\begin{array}{l}\text { It wasn't possible to blind } \\
\text { the assessor }\end{array}$ \\
$\begin{array}{l}\text { Selective reporting } \\
\text { (reporting bias) }\end{array}$ & Unclear risk & $\begin{array}{l}\text { No missing outcome data } \\
\text { Other bias study protocol is not }\end{array}$ \\
\end{tabular}

Table 6: Risk of bias (yazdani 2010):

\begin{tabular}{|c|c|c|}
\hline $\begin{array}{l}\text { Random } \\
\text { generation } \\
\text { bias) }\end{array}$ & High risk & $\begin{array}{l}\text { The } 20 \text { patients were } \\
\text { divided randomly and } \\
\text { equally into } 2 \text { groups age } \\
\text { and sex matched }\end{array}$ \\
\hline $\begin{array}{l}\text { Allocation concealment } \\
\text { (selection bias) }\end{array}$ & Unclear risk & $\begin{array}{l}\text { The study doesn't include } \\
\text { any description of } \\
\text { allocation concealment }\end{array}$ \\
\hline $\begin{array}{l}\text { Blinding of participants } \\
\text { and personnel } \\
\text { (performance bias) }\end{array}$ & Unclear risk & $\begin{array}{l}\text { it wasn't mentioned if the } \\
\text { participants were blinded } \\
\text { or not }\end{array}$ \\
\hline $\begin{array}{l}\text { Blinding of outcome } \\
\text { assessment (detection } \\
\text { bias) }\end{array}$ & Low risk & $\begin{array}{l}\text { It wasn't possible to blind } \\
\text { the assessor }\end{array}$ \\
\hline $\begin{array}{l}\text { Incomplete outcome } \\
\text { data (attrition bias) }\end{array}$ & Low risk & No missing outcome data \\
\hline $\begin{array}{l}\text { Selective reporting } \\
\text { (reporting bias) }\end{array}$ & Unclear risk & $\begin{array}{l}\text { The study protocol is not } \\
\text { available }\end{array}$ \\
\hline Other bias & Low risk & Non noted \\
\hline
\end{tabular}

Table 7: Risk of bias (He 2011):

\begin{tabular}{|c|c|}
\hline $\begin{array}{ll}\text { Random } & \text { sequence } \\
\text { generation } & \text { (selection } \\
\text { bias) } & \end{array}$ & Unclear risk \\
\hline $\begin{array}{l}\text { Allocation concealment } \\
\text { (selection bias) }\end{array}$ & Unclear risk \\
\hline $\begin{array}{l}\text { Blinding of participants } \\
\text { and personnel } \\
\text { (performance bias) }\end{array}$ & Unclear risk \\
\hline $\begin{array}{l}\text { Blinding of outcome } \\
\text { assessment (detection } \\
\text { bias) }\end{array}$ & Low risk \\
\hline $\begin{array}{l}\text { Incomplete outcome } \\
\text { data (attrition bias) }\end{array}$ & Low risk \\
\hline $\begin{array}{l}\text { Selective reporting } \\
\text { (reporting bias) }\end{array}$ & Unclear risk \\
\hline Other bias & Low risk \\
\hline
\end{tabular}

The study doesn't include any description of the selection

The study doesn't include any description of allocation concealment

it wasn't mentioned if the participants were blinded or not

It wasn't possible to blind the assessor

No missing outcome data

The study protocol is not available

Non noted 


\section{DISCUSSION}

Temporalis muscle flap can be a good choice for interpositional graft. The advantages of such flap are close proximity to the surgical area, which can be used from the same incision; good blood supply; easy preparation and harvesting; and minimal cosmetic and functional morbidity at the donor site ${ }^{[7]}$. Criticism of TMF includes its short arc of rotation, used only for moderate sized and small defects measuring not more than 4 to $8 \mathrm{~cm}$, and inability to reach the midline ${ }^{[8]}$. Postsurgical radiotherapy can lead to fibrosis of flap ${ }^{[9]}$. It cannot provide adequate bony reconstruction of maxillary defects and orbital floor. Also, it may be associated with limited mouth opening ${ }^{[10]}$. Rapidis et al proposed that the risk of partial dehiscence of this flap is high if the defect more than $6 \mathrm{~cm}-4 \mathrm{~cm}^{[11]}$ all clinical trials articles founded in the literature were about using the TMF as interpositional graft and we can consider this flap as a perfect interpositional material due to its close proximity to the TMJ and high vascularity, other articles mentioned many uses for the TMF but were not clinical trials, the most common uses for the flap are the maxillary reconstruction and closure of oroantral communication. Outcome data were inconsistently recorded in all articles. Oral food intake started most often 1 week after the surgery but ranged from postoperative day 1 to day 13 . Most patients resumed a normal diet during follow-up. When the temporalis muscle flap was used for reconstruction of the cleft palate, most of these patients had resolution of nasal regurgitation. Data for speech were not available in studies. Most of patients had functional or understandable speech when a temporalis muscle flap was used for intraoral defects reconstruction. Most studies that reported a temporalis flap for palatal fistula reconstruction showed improved velopharyngeal function $^{[12]}$. Temporal hollowing is commonly caused by atrophy of the superficial temporal fat pad. Its incidence is reported to be as high as $6 \%$ after coronal approach operation $^{[13]}$. Temporary facial paralysis occurred in cases and resolved within 2 months. However, the article included both temporalis flaps and temporoparietal fascia flaps and the author did not specify in which group the facial paralysis occurred. Permanent facial paralysis was not reported in the literature. After reviewing the literature the success rate of using the TMF as interpositional material is very high, but more researches are needed to put a constant measurement of success by using the TMF as a control group and follow up period not less than 1 year.

\section{Future directions: reconstruction of skull base}

The number of articles reporting the use of the temporalis flaps for head and neck defects reconstruction has grown rapidly in recent years. Although the temporalis muscle flap (TMF) is a valuable reconstructive technique utilized in a variety of challenging defects. However, its use for repair of skull base defects is less commonly reported ${ }^{[14]}$. So a new potential reconstruction site is the skull base.

\section{CONCLUSION}

A temporalis muscle flap is a versatile reconstruction option for medium and large sized defects of the oral cavity, oropharynx, nasal septum and other less commonly exploited sites. The advantages of this flap considerably outweigh its disadvantages. Many modifications have been recently developed to increase the width, the length, or to avoid complications, therefore expanding the scope of use of this flap. Care should be taken when considering using the modified TMF for reconstruction as there is a possible trend toward a higher complication rate of necrosis and venous congestion. New studies are exploring new indications and applications of this flap and results are very promising so far for its use in skull base reconstruction. This flap holds great potential in many aspects and is worth further investigational studies. Further studies should focus on higher levels of evidence studies than case reports and case series.

\section{CONFLICT OF INTEREST}

The authors declare no conflict of interest.

\section{REFERENCES}

1. Andrades $\mathrm{P}$, Militsakh O, Hanasono MM, Rieger J, Rosenthal EL. Current strategies in reconstruction of maxillectomy defects. Archives of otolaryngology--head and neck surgery. 2011; 137 (8): 806 - 12.

2. Cenzi R, Carinci F. Calvarial bone grafts and temporalis muscle flap for midfacial reconstruction after maxillary tumor resection: a long-term retrospective evaluation of 17 patients. The Journal of craniofacial surgery. 2006; 17 (6): 1092 - 104.

3. Chang EI. My first 100 consecutive microvascular free flaps: pearls and lessons learned in first year of practice. Plastic and reconstructive surgery Global open. 2013; 1 (4): e27 - e.

4. Speculand B. The origin of the temporalis muscle flap. The British journal of oral and maxillofacial surgery. 1992; 30 (6): 390 - 2.

5. Krzymański G, Dąbrowski J, Przybysz J, Domański W, Biernacka B, Piętka T. Temporal muscle flap in reconstruction of maxillo-facial tissues. Contemporary oncology (Poznan, Poland). 2012; 16 (3): 244 - 9.

6. Aum JH, Kang DH, Oh SA, Gu JH. Orthodromic transfer of the temporalis muscle in incomplete 
facial nerve palsy. Archives of plastic surgery. 2013; 40 (4): 348 - 52.

7. Pogrel MA, Kaban LB. The role of a temporalis fascia and muscle flap in temporomandibular joint surgery. Journal of oral and maxillofacial surgery: official journal of the American Association of Oral and Maxillofacial Surgeons. 1990; 48 (1): 14 - 9.

8. Abubaker AO, Abouzgia MB. The temporalis muscle flap in reconstruction of intraoral defects: an appraisal of the technique. Oral surgery, oral medicine, oral pathology, oral radiology, and endodontics. 2002; 94 (1): 24 - 30.

9. Hanasono MM, Utley DS, Goode RL. The temporalis muscle flap for reconstruction after head and neck oncologic surgery. The Laryngoscope. 2001; 111 (10): 1719 - 25.

10. Wong TY, Chung CH, Huang JS, Chen HA. The inverted temporalis muscle flap for intraoral reconstruction: its rationale and the results of its application. Journal of oral and maxillofacial surgery: official journal of the American Association of Oral and Maxillofacial Surgeons. 2004; 62 (6): 667 - 75.

11. Rapidis AD, Alexandridis CA, Eleftheriadis E, Angelopoulos AP. The use of the buccal fat pad for reconstruction of oral defects: review of the literature and report of 15 cases. Journal of oral and maxillofacial surgery : official journal of the American Association of Oral and Maxillofacial Surgeons. 2000; 58 (2): 158 - 63.

12. Brennan T, Tham TM, Costantino P. The Temporalis Muscle Flap for Palate Reconstruction: Case Series and Review of the Literature. International archives of otorhinolaryngology. 2017; 21 (3): 259 - 64.

13. Park IH, Kwon H, Kim SW. Cryptogenic Temporal Hollowing. Archives of craniofacial surgery. 2016; 17 (4): 218 - 21.

14. Smith JE, Ducic Y, Adelson RT. Temporalis muscle flap for reconstruction of skull base defects. Head and neck. 2010; 32 (2): 199 - 203. 